\title{
Detection of Volatile Aroma Compounds of Morchella by Headspace Gas Chromatography Mass Spectrometry (HS-GC/MS)
}

\author{
Hatıra TAŞKIN \\ University of Çukurova, Facultyof Agriculture, Department of Horticulture, 01330, Adana, Turkey; hatirataskin1@gmail.com
}

\begin{abstract}
This study was conducted at the Horticulture Department of Çukurova University, Adana, Turkey, in 2010 to determine the volatile aroma compounds of Morchella mushroom. Fresh samples of Morchella esculenta (Sample 1) and Morchella elata (Sample 2) were collected from Çanakkale (Sample 1) and Mersin (Sample 2) provinces in Turkey in the spring of 2010. Volatile aroma compounds were analyzed by headspace gas chromatography mass spectrometry (HS-GC/MS). A total of 31 aroma compounds were identified in the 2 analyzed samples: 7 alcohols, 7 esters, 7 ketones, 3 acids, 2 aldehydes, 1 terpene, phenol, 1-propanamine, geranyl linalool, and quinoline. Seventeen aroma components were identified in Sample 1, and 18 compounds were found in Sample 2. Phenol was determined as the major aroma compound in both Sample 1 and Sample 2, at 50.888\% and 58.293\% content, respectively. Alcohols, especially 1-octen3-ol, were detected as the second major aroma components in Sample 1 and Sample 2, at 15.500\% and 5.660\% content, respectively. Carbamic acid, methyl ester was found only in Sample 1, at 11.379\% content. The aroma components detected in the two samples differed. 1-Octadecanol; cyclooctylalcohol; trans-2-undecen-1-ol; butanoic acid, butyl ester (CAS); carbamic acid, methyl ester; 2-ethylhexyl2-ethylhexanoate; phthalic acid, decyl isobutyl ester; 2,2,4-trimethyl-1,3-pentanediol diisobutyrate; decanal; nonanal; 7,9-di-tert-butyl1-oxaspiro(4.5)deca-6,9-diene-2,8-dione; 2,5-cyclohexadiene-1,4-dione; 2,6-bis(1,1-dimethylethyl); and trans-alpha-bisabolene were detected only in Sample 1. Ethanol; silanediol, 2-methylaminoethanol; L-alanine, ethyl ester; carbonic acid, dodecyl isobutyl ester; acetic acid; butanoic acid; 2,3,4H-pyran-4-one; 5,9-undecadien-2-one; cyclooctene; 2-cyclopenten-1-one; 1-propanamine; geranyl linalool; and quinoline were determined only in Sample 2.
\end{abstract}

Keywords: alcohol, carbamic acid, Morel, phenol, 1-Octen-3-ol

\section{Introduction}

Morels (Morchella spp.) are among the most valuable and important mushrooms because of their taste and commercial value. These mushrooms generally appear in pine forests (Pinus brutia, Pinus nigra) in Turkey from March to June. They are picked in regions in which they are well known and transported to European countries dried or fresh. Morels provide significant income to the people living near the forests, who could sell them fresh to the companies that export the mushrooms, for approximately $30 \$ / \mathrm{kg}$ in the beginning of the morel season. After India and Pakistan, Turkey is one of the most important morel exporter countries. It is geographically close to European Union countries, a location which, according to other exporter countries, gives Turkey an important advantage in shipping fresh morel to European destinations (Pilz et al., 2007). People prefer to eat this mushroom not only for its nutritional value but also for its good taste (Pilz et al., 2007) Iqbal (1993) reported that Morchella is low in calories, rich in minerals, and contains $42 \%$ protein in dry samples. Yildiz et al. (2004) determined the crude protein of Morchella conica and M. esculenta as 22.6 and 26.8 (calculated as $\mathrm{N} \times 6.25)$, respectively. Gençcelep et al. (2009) determined the mineral contents of Morchella as $1.92 \mathrm{mg} / \mathrm{g}$ magnesium, $0.87 \mathrm{mg} / \mathrm{g}$ calcium, $20.4 \mathrm{mg} / \mathrm{g}$ potassium, 0.08 $\mathrm{mg} / \mathrm{g}$ sodium, $2.92 \mathrm{mg} / \mathrm{g}$ phosphorus, $203 \mathrm{mg} / \mathrm{g}$ iron, 133 $\mathrm{mg} / \mathrm{g}$ zinc, $73.4 \mathrm{mg} / \mathrm{g}$ copper, and $16.9 \mathrm{mg} / \mathrm{g}$ manganese in $M$. vulgaris; and $1.82 \mathrm{mg} / \mathrm{g}$ magnesium, $0.85 \mathrm{mg} / \mathrm{g}$ calcium, $23.5 \mathrm{mg} / \mathrm{g}$ potassium, $0.18 \mathrm{mg} / \mathrm{g}$ sodium, $3.49 \mathrm{mg} / \mathrm{g}$ phosphorus, $195 \mathrm{mg} / \mathrm{g}$ iron, $98.9 \mathrm{mg} / \mathrm{g}$ zinc, $62.6 \mathrm{mg} / \mathrm{g}$ copper, $54.7 \mathrm{mg} / \mathrm{g}$ manganese in $M$. esculenta.

Quality is a very important aspect of edible mushrooms and is dependent on many factors, such as colour, texture, and aroma. Mushrooms contain a lot of aroma components, including odour and taste, that are responsible for determining their chemical components. The aroma compounds of mushrooms can be detected with different techniques. However, in new researches, gas chromatography mass spectrometry (GC/MS) is the most common technique used to determine volatile aroma compounds. Many researchers have identified the aroma compounds in different mushrooms using GC/MS: MacLeod and Panchasara (1983) in Agaricus bisporus; Breheret et al. (1997) in 82 wild mushroom species; Cho et al. $(2007,2008)$ in Tricholoma matsutake; Pinho et al. (2008) in eleven edible mushrooms; Li-Juan and Gung-zhu (2010) in Tricholoma matsutake Sing.; and Leffingwell and Alfrod (2011) in Calvatia. 
Morchella is one of the most common mushrooms in Turkey, being found in almost every region of the country. Several morphological (Solak et al., 2007) and molecular (Taşkın et al., 2010, 2012) studies have been done to identify the species in Turkey. However, there is no detailed study on the aroma components of this mushroom. Thus, the purpose of this research was to determine the aroma components of Morchella by headspace (HS)-GC/MS.

\section{Materials and methods}

Fresh morel samples collected from two different provinces in Turkey were used as materials in this study. The samples were collected from Çanakkale (Sample 1: Morchella esculenta) and Mersin (Sample 2: Morchella elata) provinces in the spring of 2010. Volatile compounds were analyzed on an $\mathrm{HS}-\mathrm{GC} / \mathrm{MS}$ apparatus equipped with an HP-5 MS $(30 \mathrm{~m} \times 0.25 \mathrm{~mm} \times 0.25 \mu \mathrm{m})$ fusedsilica capillary column. Helium $(1 \mathrm{ml} / \mathrm{min})$ was used as

Tab. 1. Volatile Composition of Morchella by Headspace Gas Chromatography Mass Spectrometry (HS-GC/MS)

\begin{tabular}{|c|c|c|c|}
\hline R.T. & Compound name & Area \%-S1 & Area $\%-S 2$ \\
\hline \multicolumn{4}{|l|}{ Alcohol } \\
\hline 2.200 & Ethanol & ND & 5.310 \\
\hline 7.275 & 1-Octen-3-ol & 15.500 & 5.660 \\
\hline 30.634 & 1-Octadecanol & 0.368 & ND \\
\hline 9.680 & Cyclooctylalcohol & 1.398 & ND \\
\hline 3.49 & Silanediol & ND & 1.417 \\
\hline 2.15 & 2-Methylaminoethanol & ND & 0.157 \\
\hline 9.674 & Trans-2-Undecen-1-ol & 0.812 & ND \\
\hline \multicolumn{4}{|l|}{ Ester } \\
\hline 18.489 & Butanoic acid, butyl ester (CAS) & 0.576 & ND \\
\hline 2.212 & Carbamic acid, methyl ester & 11.379 & ND \\
\hline 1.94 & L-Alanine, ethyl ester & ND & 3.044 \\
\hline 24.410 & 2-Ethylhexyl-2-ethylhexanoate & 0.822 & ND \\
\hline 30.477 & Phthalic acid, decyl isobutyl ester & 1.654 & ND \\
\hline 16.622 & 2,2,4-Trimethyl-1,3-pentanediol diisobutyrate & 0.321 & ND \\
\hline 18.77 & Carbonic acid, dodecyl isobutyl ester & ND & 1.382 \\
\hline \multicolumn{4}{|l|}{ Acid } \\
\hline 24.284 & Propanoic acid & 3.459 & 0.918 \\
\hline 3.12 & Acetic acid & ND & 3.937 \\
\hline 2.18 & Butanoic acid & ND & 0.069 \\
\hline \multicolumn{4}{|l|}{ Aldehyde } \\
\hline 13.674 & Decanal & 0.378 & ND \\
\hline 10.731 & Nonanal & 1.275 & ND \\
\hline \multicolumn{4}{|l|}{ Ketone } \\
\hline 31.534 & 7,9-Di-tert-butyl-1-oxaspiro(4.5)deca-6,9-diene-2,8-dione & 0.264 & ND \\
\hline 21.021 & 2,5-Cyclohexadiene-1,4-dione,2,6-bis(1,1-dimethylethyl) & 0.359 & ND \\
\hline 21.335 & 2,6-Di-T-butyl-4-methylene-2,5-cyclohexadiene-1-one & 0.236 & 0.594 \\
\hline 12.02 & 2,3,4H-pyran-4-one & ND & 2.755 \\
\hline 20.57 & 5,9-Undecadien-2-one & ND & 0.349 \\
\hline 7.30 & Cyclooctene & ND & 1.303 \\
\hline 6.57 & 2-Cyclopenten-1-one & ND & 1.049 \\
\hline \multicolumn{4}{|l|}{ Terpene } \\
\hline 21.915 & Trans-alpha-bisabolene & 0.850 & ND \\
\hline \multicolumn{4}{|l|}{ Phenol } \\
\hline 22.223 & phenol, 2,6-bis(1,1-dimethylethyl)-4-methyl & 50.888 & 58.293 \\
\hline 2.11 & 1-Propanamine & ND & 3.980 \\
\hline 23.68 & Geranyl linalool & ND & 0.498 \\
\hline \multirow[t]{2}{*}{21.49} & Quinoline & ND & 0.524 \\
\hline & Other compounds & 9.461 & 9.761 \\
\hline
\end{tabular}

RT: Retention time;

ND: Not detected 
124

carrier gas. The SPME holder, for manual sampling, and the fibres used in this study were purchased from Supelco (Bellefonte, PA). Polydimethylsiloxane (PDMS) fibres of 100-mm diameter were used; these were conditioned for 1 $h$ at $240^{\circ} \mathrm{C}$ in the GC injector port before use and cleaned between analysis to prevent contamination. The injector temperature was $250^{\circ} \mathrm{C}$, set for splitless injection. The oven conditions were set to $50^{\circ} \mathrm{C}$ for $1 \mathrm{~min}$, after which the temperature was increased to $200^{\circ} \mathrm{C}$ at a rate of $4^{\circ} \mathrm{C} /$ min. Thermal desorption was allowed for $1.5 \mathrm{~min}$. The detector temperature was $280^{\circ} \mathrm{C}$. The components were identified by comparison of mass spectra and retention time data complemented with Wiley, flavour, and NIST GC/MS libraries.

\section{Results and discussion}

A total of 31 aroma compounds were identified in the 2 analyzed samples. Tab. 1 shows the obtained results. Alcohols, such as ethanol, 1-octen-3-ol, 1-octadecanol, cyclooctylalcohol, silanediol, 2-methylaminoethanol, and trans-2-undecen-1-ol were detected. Among these determined alcohols, only 1-octen-3-ol was identified in both samples. 1-Octadecanol, cyclooctylalcohol, and trans2-undecen-1-ol were detected only in Sample 1, whereas ethanol, silanediol, and 2-methylaminoethanol were determined only in Sample 2. 1-Octen-3-ol is one of the most important mushroom alcohols, and the highest content of $15.500 \%$ was obtained from Sample 1. 1-Octen3-ol (mushroom, butter, resinous), 3-octanol (fruity, cod liver oil, citrus, weakly nutty, fungal), 1-octanol (fruityflowery, sweet soap, orange, waxy, sweet), 1-octen-3-one (boiled mushrooms, metallic, fungal, wild mushroom), 3-octanone (fruity, sweet, musty, floral, lavender, sweet ester), 2-octen-3-ol, and 3-octanal are the well-known and common aroma compounds (Jong and Birmingham, 1993; Taylor and Linforth, 2010).

Three different acid compounds were identified. Butanoic acid and acetic acid were determined in Sample 2. Propanoic acid was found in both Sample 1 and Sample 2. Decanal and nonanal were determined as aldehydes, and both were observed in Sample 1. Trans-alpha-bisabolene was found in Sample 1 as terpene. The phenol content was very high in both samples (Sample 1: 50.888\% and Sample 2: 58.293\%). 1-Propanamine, geranyl linalool, and quinoline were observed only in Sample 2. Seven esters were identified. The compounds 2,2,4-trimethyl-1,3-pentanediol diisobutyrate; butanoic acid, butyl ester (CAS); carbamic acid, methyl ester; 2-ethylhexyl-2-ethylhexanoate; and phthalic acid, decyl isobutyl ester were detected in Sample 1, whereas L-alanine, ethyl ester and carbonic acid, dodecyl isobutyl ester were observed in Sample 2.

Phenol was determined as the major aroma compound. Lee et al. (2010) and Tsai et al. (2009) reported on the antioxidant effects of phenolic compounds in mushrooms. Alcohols, especially 1-octen-3-ol, were detected as the second major aroma components in Sample 1 and Sample 2 , at $15.500 \%$ and $5.660 \%$ content, respectively. Esters are used in the cosmetics industry because of their intrinsic odour. Ketones, such as acetone, steroids, and some sugars, are commonly used in industrial, medical, and chemical applications. Sample 2 was found to be very rich in terms of ketones, with $6.05 \%$ content.

\section{Conclusions}

Morels (Morchella spp.) are among the most valuable and important mushrooms consumed all over the world, especially in Europe, because of their aroma. The commercial value of this mushroom species is increasing year by year due to increasing demand. Morchella is low in calories, rich in minerals, and has $42 \%$ protein content in dry samples. People prefer to eat this mushroom not only for its nutritional value but also for its good taste. In this study, the volatile aroma compounds of Morchella were determined. A total of 31 aroma components were identified (alcohols, terpenes, acids, aldehydes, ketones, and esters). Phenol was the major aroma compound in Sample 1 and Sample 2, at $50.888 \%$ and $58.293 \%$, content, respectively. Alcohols were the second major compounds, especially 1-octen-3-ol, at $15.500 \%$ content in Sample 1. Carbamic acid, methyl ester was found to be an important aroma compound, with $11.379 \%$ content in Sample 1. Whereas 17 volatile aroma compounds were identified in Sample 1 (Morchella esculenta), 18 components were detected in Sample 2 (Morchella elata). However, the aroma components detected in the two samples differed. For example, the 1-octen-3-ol content was found to be higher in Sample 1 than in Sample 2. This component is one of the most important and common mushroom aroma compounds. Carbamic acid, methyl ester was determined only in Sample 1. Some components, such as L-alanine, ethyl ester; 1-propanamine; ethanol; and acetic acid, were determined only in Sample 2.

\section{Acknowledgments}

The authors thank the Çukurova University Scientific Research Projects Coordinating Office (ÇÜ-BAPZF2009D41) for the aroma analyses.

\section{References}

Breheret S, Talou T, Rapior S, Bessière JM (1997). Monoterpens in the aromas of fresh wild mushrooms (Basidiomycetes). J Agric Food Chem 45:831-836.

Cho IH, Lee SM, Kim SY, Choi HK, Kim KO, Kim YS (2007). Differentiation of aroma characteristics of Pine-Mushrooms (Tricholoma matsutake Sing.) of different grades using gas chromatography-olfactometry and sensory analysis. J Agric Food Chem 55:2323-2328.

Cho IH, Namgung HJ, Choi HK, Kim YS (2008). Volatiles and key odorants in the pileus and stipe of pine-mushroom 
(Tricholoma matsutake Sing.). Food Chem 106:71-76.

Gençcelep H, Uzun Y, Tunçtürk Y, Demirel K (2009). Determination of mineral contents of wild-grown edible mushrooms. Food Chem 113:1033-1036.

Iqbal M (1993). International trade in non-wood forest products: an overview. Working Paper Misc/93/11, Rome, Italy, Food and Agriculture Organization of the United Nations. Sec 7.1

Jong SC, Birmingham JM (1993). Mushrooms as a source of natural flavor and aroma compounds, 345-366 p. In: Chang ST, Buswell JA, Chiu SW (Eds.). Mushroom biology and mushroom production. Chinese Univ Press, Pekin, China.

Lee H, Kalaras M, Beelman R (2010). Antioxidant Properties of Ergothioneine and Total Phenols in Mushroom Extracts. Annual IFT Meeting, 17-20 July 2010, Chicago.

Leffingwell JC, Alfrod ED (2011). Volatile Constituents of the Giant Puffball Mushroom (Calvatia gigantea). Leffingwell Reports, Vol 4.

Li-Juan L, Gung-zhu J (2010). GC-MS Analysis of Volatile Compounds in Fruitbodies of Tricholoma matsutake Sing. Food Sci 31:08.

Macleod AJ, Panchasara SD (1983). Volatile aroma components, particularly glucosinolate products, of cooked edible mushroom (Agaricus bisporus) and cooked dried mushroom. Phytochemistry 22:705-709.

Pilz D, Mclain R, Alexander S, Villarreal-Ruiz SB, Wurtz, Parks CG, McFarlane., Baker B, Molina R, Smith JE (2007). Ecology and management of morels harvested from the forests of Western North America. United States Department of Agriculture, Forest Service, Pacific Northwest Research Station General Technical Report, PNW-GTR-710.
Pinho PG, Ribeiro B, Gonçalves RF, Bapista P, Valentão P, Seabra RM, Andrade PB (2008). Aroma Compounds in Eleven Edible Mushroom Species: Relationship Between Volatile Profile and Sensorial Characteristics, Expression of Multidisciplinary Flavour Science, $12^{\text {th }}$ Weurman Flavour Research Symposium.

Solak MH, Işıloğlu M, Kalmış E, Allı H (2007). Macrofungi of Turkey. Checklist. Volume I. İzmir.

Taşkın H, Büyükalaca S, Doğan HH, Rehner SA, O’Donell K (2010). A multigene molecular phylogenetic assesment of true morels (Morchella) in Turkey. Fungal Genet and Biol 47:672-682.

Taşkın H, Büyükalaca S, Hansen K, O’Donnell K (2012). Multilocus phylogenetic analysis of true morels (Morchella) reveals high levels of endemics in Turkey relative to other regions of Europe. Mycologia 104(2):446-461.

Taylor AJ, Linforth RST (2010). Mushroom, 16 p. Food Flavor Technology, Second Edition, Wiley Blackeell.

Tsai SY, Huan SJ, Lo SH, Wu TP, Lian PY, Mau JL (2009). Flavour components and antioxidant properties of several cultivated mushrooms. Food Chem 113:578-584.

Yıldız A, Yeşil ÖF, Yavuz Ö, Karakaplan M (2004). Organic elements and protein in some macrofungi of South East Anatolia in Turkey. Food Chem 89:605-609. 